Article

\title{
Managing Sport for Public Health: Approaching Contemporary Problems with Traditional Solutions
}

\author{
Anna Aggestål * and Josef Fahlén \\ Department of Education, Umeå University, 90187 Umeå, Sweden; E-Mails: anna.aggestal@umu.se (A.A.), \\ josef.fahlen@umu.se (J.F.) \\ * Corresponding author
}

Submitted: 15 October 2014 | In Revised Form: 25 December 2014 | Accepted: 4 February 2015 |

Published: 25 June 2015

\begin{abstract}
In the area of public health, civil society involvement in attaining government objectives on physical activity participation is often carried out by voluntary sport organizations (Agergaard \& Michelsen la Cour, 2012; Österlind \& Wright, 2014; Skille, 2009; Theeboom, Haudenhuyse, \& De Knop, 2010). In Sweden, this responsibility has been given to the Swedish Sport Confederation (SSC), a voluntary and membership-based non-profit organization, granted government authority to govern Swedish sport towards government objectives (Bergsgard \& Norberg, 2010; Bolling, 2005). Research has pointed to difficulties for sport organizations to shoulder such responsibilities due to the deeply rooted logic of competition in sport and organizational structures adapted for competitive sport (Skille, 2011; Stenling \& Fahlén, 2009). This article focuses on how public health is being constructed, implemented and given meaning within the SSC. Drawing on a critical discourse approach (Fairclough \& Fairclough, 2012) this study explores the SSC's role and position in public health promotion by interviewing SSC representatives and National Sport Organizations' (NSO) general managers. Results indicate how discourses on democracy, equality and physical activity are used to legitimize the SSC's role in public health. Also, how these discourses are compromised in practice, posing challenges for organized sport in meeting objectives of public health.
\end{abstract}

\section{Keywords}

argumentation analysis; Critical Discourse Analysis (CDA); democracy; equity; physical activity

Issue

This article is part of the special issue "Sport for Social Inclusion: Critical Analyses and Future Challenges", edited by Dr. Reinhard Haudenhuyse (Vrije Universiteit Brussel, Belgium) and Professor Marc Theeboom (Vrije Universiteit Brussel, Belgium)

(C) 2015 by the authors; licensee Cogitatio (Lisbon, Portugal). This article is licensed under a Creative Commons Attribution 4.0 International License (CC BY).

\section{Introduction}

The approach of utilizing sport with the intention of contributing to fundamental change and transformation in society has received much attention within the field of "sport for development" (Girginov, 2008) over the last decade. In particular, interventions to promote social inclusion and health have been studied in many different forms and settings (Bloyce \& Smith, 2010). This text reports on a study of both these as- pects but not with the interventionist approach dominating contemporary research (Hartmann \& Kwauk, 2011). Instead it seeks to problematize interventions and sport for public health, in this case, by posing questions about organization's will, ability, readiness and propensity to act as a counteracting force against differences in sport participation and health between groups in society.

In Sweden, sport and physical activity has received a prominent position in welfare policy and is, as such, 
governed through the national objectives on public health, one of whose objectives physical activity constitutes (SOU, 2000, p. 91). The Swedish Sport Confederation (SSC), a voluntary and membership-based nonprofit organization, has, since receiving its first government grant in 1913 (Norberg, 2004), been granted permanent annual state subsidy for sport activities as the main provider of sport for the people. With a relationship more of a partnership balancing rights and obligations in a way that has been described as an implicit contract, the SSC has been assigned a government mandate to act towards objectives of physical activity and public health, but is struggling to live up to those expectations (Norberg, 2011). In the SSC's policy document (Riksidrottsförbundet, 2009) on recreational sport it is stated that health, comfort and well-being is the norm, although performance and competition often serve as a spur. Furthermore, the SSC pledges in its strategy document on public health (Riksidrottsförbundet, 2007) to undertake health related development work within the frames of all of its regular sport activities and also to make targeted efforts (such as for example exercise on prescription, adapted activities for overweight children, and activities for adults on long term unemployment or sick leave) to reach new groups with inclusion as the main goal.

During the last decade two large, nationwide sport development programmes, The Handshake (Handslaget) and The Sports Lift (Idrottslyftet), have been launched to further pursue the ambition to include more children and youth in voluntary and membershipbased club sport activities (Fahlén \& Karp, 2010; Fahlén, Eliasson, \& Wickman, 2014). Similar to its Nordic counterparts in Denmark (Ibsen, 2002), Finland (Vuori, Lankenau, \& Pratt, 2004) and Norway (Skille, 2009; Skille \& Waddington, 2006), the basic idea behind programmes has been the government commissions to national umbrella organizations for sport to develop their activities so that more children and youth (especially underrepresented and underprivileged groups) choose to participate in sport club activities, and to develop their activities so that children and youth choose to participate longer into their teens and early adulthood. While these programmes, and similar interventions in other countries (cf., Friis Thing \& Ottessen, 2010, for a study of civil society involvement in welfare policy for public health; Wickman, 2011, for equal opportunity; Theeboom, Schaillée, \& Nols, 2012, for integration; Morgan, 2013, for democracy; Mutz \& Baur, 2009, for criminality; Stenling, 2014, for youth delinquency; Grix \& Carmichael, 2012, for national identity; and Thorpe, 2014, for individual identity) have been valuable for social inclusion, some evidence indicates difficulties in relying on civil society organizations on the one hand, and in confusing physical activity with voluntary and membership-based club sport on the other hand.
Regarding the first and in relation to the empirical focus of this article, many studies (e.g., Adams, 2011; Garrett, 2004; Harris, Mori, \& Collins, 2009; May, Harris, \& Collins, 2012; Nichols, Padmore, Taylor, \& Barrett, 2012; O'Gorman, 2011; Skille, 2009, 2010, 2011; Skille \& Solbakken, 2011; Stenling, 2013, 2014; Stenling \& Fahlén, 2009) have explored the propensity, ability, readiness and will of sport organizations to fulfil policy aims formulated by external stakeholders such as the state. These studies have found that sport organizations' existing ideas, norms and values act as strongholds against policy initiatives differing too much from their core activities. Regarding the latter, critics have found that most studies cited to support the notion that sport is beneficial for public health actually refer to physical activity or exercise (and not to sport) and that sport and physical activity is not the same (Coalter, 2007). However, as noted by Bloyce and Smith (2010), Collins (2010), and Coalter (2007), less is known about how sport and health policy are enacted in practice. Paying heed to the claim by Collins (2010), that the promotion of health through physical activity with the use of voluntary and membership-based sport organizations has not been explored sufficiently, this article explores the promotion of public health in the context of Swedish sport. Answering the call made by Hylton and Bramham (2001) to direct research focus at the gap between formulation of strategies for attaining equal opportunities and the implementation of such strategies, the aims of this article are to analyse how public health is being constructed, implemented and given meaning on a strategic level within the SSC, and to discuss implications in relation to society and public health objectives. This is to understand the SSC's potential for being a national physical activity promoter and to even out differences in health between groups in society.

\section{Contextual Background}

The Swedish Sport Confederation (SSC) is, as mentioned in the introductory section, appointed by the government to act towards the national objectives of physical activity and public health, and has since 1970 been given the mandate to distribute government funds to sport organizations (Norberg, 2002). Government funds to voluntary organized and membershipbased club sport have been granted since 1913 and today amount to some $€ 210$ million (Centrum för idrottsforskning, 2013). Public funding to sport also comes in the forms of municipal support of $€ 490$ million ( $€ 360$ million to facilities and $€ 130$ million to activities and leaders, Bergsgard \& Norberg, 2010). This extensive public funding is provided as means for implementing social policy and goes out to and is used by $3,300,000$ sport club members in 20,164 Swedish sport clubs (Centrum för idrottsforskning, 2013), but is 
also distributed to some 1,000 district sport organizations (DSO, with regional authority over one specific sport), to 21 regional sports organizations (RSO, with regional authority over all sports), and to 70 national sport organizations (NSOs with national authority over one specific sport) for coordination, administration and support. These organizations are federated under one large umbrella organization with almost a monopoly on competitive sports (Bairner, 2010; Bergsgard \& Norberg, 2010). The monopoly is based on the fact that the SSC holds the role as the highest authority in voluntary organized and membership-based club sport and as a public authority in sport policy (Norberg, 2011). The role of the government has traditionally been limited to decisions on the extent of the funding and its overarching goals, while the SSC has had the mandate to decide on the means for reaching such goals. This state-SSC relationship has enabled the government to control its expenditure and the SSC to preserve its selfdetermination in a corporative collaboration. The confederation's main tasks include representing voluntary and membership-based club sport in communication with authorities, officials and the surrounding society, supporting and servicing affiliated organizations, administering and distributing government funds to affiliated organizations, stimulating sport development and research, coordinating social and ethical issues, leading and coordinating anti-doping work, coordinating international cooperation, protecting sport's historical lega$\mathrm{cy}$, and to acting as the government authority for the 51 upper secondary elite sport schools with some 1,200 students in 30 sports. The defining character of and main organizing principle for contemporary voluntary and membership-based club sport in Sweden is that of individuals forming and/or taking part as members in voluntary and membership-based sport clubs.

\section{Theoretical Approach}

Critical discourse analysis (CDA) involves normative critique of discourse and the existing social reality focused upon dialectical relations between discourse, social practice and social structure-all being conditions for, and effects of, each other (cf., Fairclough, 1992). In CDA, discourse is seen as representations of processes, relations and structures of the material, mental and social world, and also as a form of social practice and mode of action that has constructive effects. The discursive constitution of society emerges not only from ideas in people's heads, but from social practices firmly rooted in real, material social structures. According to Fiske (1994) CDA acknowledges that language (discourse) derives its meaning from particular social, historical and political contexts. CDA aims at evaluating societies in order to understand possibilities for changing them to make them better, in terms of cultivating the well-being of their members rather than undermin- ing it. The basis for developing CDA is a critique of past and current research applying a CDA perspective without connecting representations of agents' meaningmaking with actual actions via agents' practical reasoning. In approaching the construction, implementation and sense-making of public health through voluntary organized and membership-based sport in Sweden the analyses in this article rests on the most recent variant of CDA as performed by Isabela and Norman Fairclough (2012). In this variant of CDA (Fairclough \& Fairclough, 2012) discourse is viewed primarily as practical argumentation for (or against) particular ways of acting, a deliberative form of argumentation that can ground decision. It is shown how representations of actions enter as premises in arguments and that arguments based on such representations can be critically evaluated. The authors claim that an analysis and evaluation of arguments can increase the capacity of CDA to extend critique of discourse, moving from normative critique (representations) to explanatory critique (practical arguments). This statement will be put to the test in this text in using it to understand the SSC's possibilities to and obstacles for acting as the national physical activity promoter and to even out differences in health between groups in society.

In trying to make use of the proposed framework, a structure of practical reasoning and practical argumentation is employed. Practical arguments for, as well as against, certain actions (means premises) are in this approach understood as taking circumstances and goals as premises, and the circumstances (that are described in a way that fits in with the claim of action) are understood as being informed by the agents' values premises. That is, organizational leaders, in this particular case, choose certain means and actions (over others) in view of the certain circumstances they find themselves in, but also in view of their goals which are supported by their values and concerns. The basic notion is that we tend to "see" problems around us in relation to our values and concerns, which informs our goals and the means we take to achieve them. In this study and from an argumentative perspective, statements about strategies, procedures, working methods and actions that are employed in fulfilling ideas of public health are treated as representations that enter as premises in the arguments of how sport contributes to public health. In a similar way, means premises are deconstructed to identify inherent goals, circumstances and values. Finally, arguments are evaluated in terms of whether the actions are reasonable and sufficient in view of the goal and of the consequences of action. CDA has previously been employed in other studies to analyse and critique sport related discursive representations of different kinds of material, for example in Canadian Swim Program manuals (Rich \& Giles, 2014), American sports news publications (Simon-Maeda, 2013) and British national newspapers (Kelly, 2012). 
This study's approach will add to the knowledge about the relationship between discursive representations of public health and sport practice.

\section{Methodological Approach}

CDA provided the methodology for both data-gathering and analysis processes in this study. Capturing agents' practical reasoning required qualitative interviews (Kvale \& Brinkmann, 2009) and capturing the construction, implementation and sense-making of public health through voluntary organized and membershipbased sport in Sweden required a purposeful sampling (cf., Patton, 2002) of respondents together representing the collective reasoning of the SSC. Thus, respondents were chosen on the basis of their assumed knowledge about and possible influence on decisions made in relation to the object of study in this text (Bryman, 2008). Following this notion it was deemed important to select key actors with formal power and mandate to govern the confederation towards the public health aims provided by the government. Thus, key actors from the national SSC and its federated national sport organizations (NSO), with national authority over their respective sport, were selected.

SSC representatives were chosen guided by an ambition to capture the strategic dimensions of policy enactment. That is, leaders in formal positions having access to resources and mandate to allocate these within the organization, making them able to influence Swedish sports development. The selection resulted in six representatives: the chairperson of the confederation, the director of sports policy, the director of sports development, the director of economy, the director of recreational sport for children and youth and recreational sport for adults. Four of these representatives also hold a position on the SSC's board of directors, the highest governing body in the organization.

The purposeful selection of NSOs aimed at providing information-rich examples. Therefore a sample of NSOs was made on each organization's merits as distinguishing itself as being more public health oriented. This selection was assisted by SSC representatives. According to the SSC representatives, a few NSO's were described as forerunners within the sports movement by arranging sports suitable "for all", by delivering sport activities organized with the purpose of the participants being physically active and having fun without goals set for competition and performance, and by participating in targeted interventions in line with public health goals. Four NSOs, out of the total of 70 , were selected: company sports, gymnastics, school sports and academic sports. Each NSO was represented by its general manager with formal power and mandate to govern the organization. In total, this study is based on interviews with ten organizational leaders: six SSC representatives and four NSO general managers. The re- spondents were contacted via email and telephone in advance and invited to participate in a telephone interview. Information was given about the study's purpose and how it would be published. After that, the respondents agreed to participate in interviews, and times for the interviews were booked. The semistructured interview guide had the key objectives in state sport policy and public health policy as a starting point, narrowed down to a couple of question areas: sport's significance for public health; encouraging participation, physical activity and recreational sport of the population; offering sport "for all"; reducing societal differences in sport participation and health; targeted efforts for public health; and inter-sectorial collaboration. The semi-structured format of the interviews enabled the respondents to talk about how they, within their organization, are implementing the above mentioned public health related objectives in their everyday practice. This, in turn, allowed for the conversation to move beyond common (political) rhetoric and discourse towards richer knowledge about how "sport for public health" is implemented and why (Kvale \& Brinkmann, 2009). The interviews were conducted by the first author on the telephone from the author's office. The interviews lasted approximately one hour, were recorded and transcribed verbatim by the first author.

Data were analysed in several careful reviews, marking and sorting out arguments about the meaning of public health and in what way sport is valuable for and promotes better overall health. With the CDA perspective employed, these arguments were collected into themes which can be seen as representations of the respondents' understanding and ideas of sport's significance for public health. The themes are: democracy, equality, recreation and physical activity. In order to take the analysis a further step beyond those representations and to explore how the respondents are putting them into practice within their respective organizations, the interviews were analysed using an argumentative perspective on discourse (Fairclough \& Fairclough, 2012), as outlined under the Theoretical approach section. An illustrative example is offered to clarify the process in the present study. Since the respondents were asked to talk about how they implement "sport for public health", the means for implementation were identified in the first step of the analysis. One example of means for implementation given was the government programme "The sports lift". As a second step, the line of argumentation connected to those means was analysed with regard to identifying the circumstances in relation to the means and also the values and concerns. For example, the circumstances for "The sports lift" could be argued on basis of concerns about recruiting more members. The values connected to these concerns and motivating the description of the circumstances could be linked to 
traditional competitive sport activities and related performance skills. This means ("The sports lift") in relation to the (stated) goal of reaching new and other groups of people, could then be evaluated.

\section{Findings}

Aiming at an understanding the SSC's potential for being a national physical activity promoter and to even out differences in health between groups in society, the findings are presented thematically following the respondents' lines of argumentation.

\subsection{The Significance of Sport for Public Health}

When asked questions about what significance sport has for the public health of the Swedish population the respondents claimed that sport's role in public health is important in several ways. The statements given about public health, sport's significance for and contribution to it, are very much in line with the key objectives in state sport policy. A common argument among the respondents is that the sport movement already delivers public health through its regular activities and that sport is entitled to government support for doing just that and that alone, without having to perform further specific actions such as, for example, those connected to the government programmes presented in the introduction, or yet other targeted efforts such as exercise on prescription, adapted activities for overweight children and activities for adults on sick leave. This line of reasoning is exemplified by one respondent: "The good in sport is sport itself, so to speak...just the fact that sport exists makes it a health perspective".

When scrutinizing the arguments within this line of reasoning - that sport is inherently beneficial for public health-four main discourses come to the fore: democracy, equality, recreation and physical activity. The first discourse is about how sport participation fosters democracy and that being offered opportunities to exercise influence is key to public health. Schooling in democratic values is a cornerstone in Swedish voluntary and membership-based organizations and by offering members voting rights, influence and power, members are included and empowered. Connected to the democracy discourse is the argument that sport promotes equality. By stating that sport is an activity for all, regardless of age, gender, ethnicity, religion, sexual orientation, or social and financial background; it is again argued that sport is intimately connected to public health due to its inclusive nature. The inclusiveness in extension brings about the third argumentrecreation. Since all are included, sport makes up an arena for social interaction which in turn promotes a sense of community and belonging. Community and belonging, it is asserted, is then instrumental for public health. The argument of recreation is also based on the view of sport as something you do simply because it is fun, not based on goals for performance improvement or competition. Fourth and finally, it is argued, sport is healthy on the merits of its physical character. Thus, this particular argument contains little else than the first statements given about public health, sport's significance for and contribution to it, which in turn are little more than echoes of the key objectives in state sport policy. By that it shows how cemented the hegemonic discourse about the value of sport is and how the sport-public health relationship is constructed through circular arguments.

\subsection{The Implementation of Sport for Public Health}

When discussing how sport for public health is implemented in practice within the respondents' respective organizations, the circular arguments remain. This is visible in the general opinion among the respondents; that their main responsibility is to provide support for and create the best possible conditions for the organization and its members to "do sport". In an attempt to move beyond this seemingly self-evident argument, respondents were asked to specify what they as professionals in their day-to-day operations do to meet the goals of sport for public health. Their descriptions are then oriented around activities such as advocacy "for sport" and lobbying government agencies and community representatives such as policy makers, national and local politicians, business leaders and school leaders. The lobbying of public officials is specifically focused on arguing for a more "open" and "free" distribution of public funds to sport with less regulation and control. By that, it is claimed, sport is better equipped to act as public health promoter.

Then, respondents also talked about taking internal measures to further facilitate the implementation of public health through sport-to influence the organization "for public health" from within. The measures referred to are the ongoing restructuring of the organizations spurred by a shared argument that voluntarily organized and membership-based club sport needs to change and broaden its activities and thereby its target groups. It is, however and simultaneously, emphasized that Swedish sport organizations are in fact part of a voluntary and democratically governed popular movement acting on behalf of its members who are in the end those in charge of the what, how, when and why of sport clubs' activities: "It's not like a company with subsidiaries that one can say what they should do". Thus, the concept of democracy, which was one of the arguments given by the respondents for sport's importance for public health, returns but seems to be a double-edged sword. On the one hand, voluntariness and active memberships is pointed to as a vehicle for public health as members can exercise their democratic rights in an organization and thereby be empowered, 
which is argued to contribute to public health. On the other hand, it is complicated from the point of view of the limited possibility to influence or control the organization in any direction since the respondents are acting on behalf of the members.

Nevertheless, several of the means employed to "do public health" are aiming to influence and change the organizations' culture in a top-down manner. In order for sport to be more inclusive and open "to all", and to be able to fulfil the function as the national physical activity promoter, respondents claim that the organization's inherent logic of competition and performance needs to change: "We are trying to get the NSOs to review their operations and to consider what they might need to change to get people outside the sport movement to want to join". This quote might indicate that promoting public health is thought of as best being realized by making efforts to reach new groups of people, such as the inactive or sedentary, and at the same time striving against "sport for all". The practical argumentation for how these efforts are implemented shows how increasing the number of members is a means to receive more legitimacy and funding, which may benefit competitive sports in the end. The goal to increasing membership, and not necessarily to even out differences in health, is identified by examples of recruitment activities that target former sport members or individuals that have previously been physically active. There are also examples of the contrary, for instance the NSO of school sports cooperates with other NSOs organizing "non-traditional sports" (boule petanque is given as one example) in an attempt to attract children not interested in "regular club sports" such as soccer or gymnastics. The respondent representing the NSO for school sports explains: "If we are serious about making a better sports movement which more people feel they want to be a part of, it is necessary to influence the sport clubs to stop thinking in terms of the logic of competition and performance and to broaden their perception of for whom they exist". Thus, similar to the double-edged nature of the concept of democracy, equality is equally being used both as an argument for sport's significance for public health and as a measure taken to implement ideas for public health.

However, including new groups of people in the pursuit of realizing "sport for all" is also problematized by the respondents. While the ambition is very much on the agenda in the ongoing development work, it is argued by some of the SSC representatives that reaching new groups involves more than just offering more or perhaps "non-traditional sport activities". They claim that the whole organizational structure of sport has to change in order for sport to be able to move away from a priority on competition and ranking of performance. As an example they point to the most recent and still ongoing sport development programme,
The Sports Lift, (alluded to in the introduction of this paper) in which actions are taken aiming at broadening the sport movements' uptake. While such programmes are argued to be valuable and referred to as means to fulfil the public health objectives, they cannot be expected to repair the mechanisms behind the problem: "We cannot just make these additional investments all the time, we have to change internally, and there really is no quick fix". Since regular club sport activities, the respondents elaborate, are not organized with recreation and physical activity for the participants as their main aim, it is far-fetched to expect participants who are first and foremost interested in physical exercise. In addition it appears as that a particular type of participant is not very interesting for a sport club to attract either: "The sport movement has traditionally not been interested in people who are not interested in competing in sports but only to move for the sake of exercise".

The NSO representatives also seem to be aware of how the sporting activities they provide and the groups of people they attract fit in with contemporary societal public health ambitions. The NSO representative for company sports concludes that their organization seem to attract many leaders with specific skills and interest in delivering recreational physical activities for young people and adults, a direction that happens to fit well into a public health profile. This particular NSO has, in recent years, involved all its affiliated sport clubs in extensive strategic planning activities and development work which has resulted in a "business" strategy taking a stand for concepts such as health and public health. Some fractions within the NSO have voiced opinions to further include various kinds of public health activities (such as smoking prevention, dietary advice, physical activity on prescription), but the strategy work has resulted in a more consolidated offering of activities: "Our contribution to public health is to improve the physical health of our members by physical activity". There are still affiliated sport clubs working towards specific target groups (for example overweight children and people on sick leave) and in cooperation with county and municipality administrations, but experiences from such efforts have shown that such activities are often afflicted with problems of coordination and tend to require additional funding besides regular government grants. The NSO representative for gymnastics expands on the difficulties in implementing physical activity on prescription. Since activities for people granted a prescription are to be provided during the day and voluntary leaders only are available in the evenings after work, it has proven difficult to coordinate "supply" and "demand" resulting in a decline in interest from the activity leaders to perform such duties. The NSO representative for academic sports reports being more successful and exemplifies this with a large externally funded project aiming at recruiting physically inactive students, which has resulted in the 
development of a model for getting young people started with physical activity. In conclusion with regard to implementing sport activities for public health, the four NSOs represented in this study seem to be in line with public health objectives. However and importantly, it appears difficult to provide activities that are disconnected from the logic of competition and performance: "In the traditional sport club the focus of course is on improvement of performance, on the next game or next competition".

\subsection{The Potential of Sport for Public Health}

While the respondents argue that sport already delivers public health through its existing and regular activities, they also highlight that sport holds a big potential for contributing to public health even more in the future. The potential is argued to lie within the reorientation of the larger sport movement which has been initiated and which is hoped to bring about a change of direction, making the sport movement more inclusive and open to all. At the same time, the respondents argue strongly that it is completely voluntary for sports clubs to take on health promotion activities, and that the organization is, by no means, to be perceived as a public health supplier for the government-it simply has no obligation to take individual responsibility for public health. While the respondents all paint a picture of an organizational willingness to be an advocate for health and to strive for contribution to public health, they at the same time point to the fact that willingness, advocacy and perseverance is all in the hands of the existing members. In relation to the latter, the respondents are not too optimistic since the existing priority in most sport clubs appears to be to preserve the longstanding tradition of sport activities: "Too much focus on public health interventions can make us lose focus on sport, which is the core and foundation". This "too much focus" is seen as problematic in other ways too by one of the respondents who claims that there are leaders within the organization that on their own initiatives "take on too much responsibility for public health and put in too much work without getting paid for it". Such an argument is particularly interesting in the light of the ascribed value of grassroots anchored initiatives and the experienced problem of leaders being guided too much by the logic of competition and performance. Simultaneously it is argued that it is difficult to design activities with a public health perspective, instead of with the traditional competition and performance perspective. It requires a different kind of leadership and competence which cannot be expected of the voluntary leaders in Swedish sport, even if the respondents acknowledge that there do exist leaders holding such competence. The internal education system doesn't seem equipped to prepare leaders for such leadership, with the health aspects included in these programmes being restricted to basic knowledge in relation to the specific sport in question and often reduced to injury prevention and treatment.

In conclusion with regard to the potential of sport for public health, the respondents appear to be somewhat ambivalent. On the one hand they claim that sport is in its existing form promotive of public health and has the potential to be even more so in the future. On the other hand they see obstacles in the form of self-determining members and leaders guided by traditions and the logic of competition and performance. One of the respondents elaborates on the latter and highlights the importance of the sports movement to be built on voluntary initiatives - that possible public health related activities carried out within the organization must be based on the members' own desires and interests. However, the focus of the local sport clubs, as another representative concludes, is not to administer various social problems: "One probably should not overestimate the capacity of sport to play the role of public health promoter".

\section{Conclusions}

The ambitions of this article were to show how public health is implemented and given meaning within Swedish sport and to add to the broader understanding of voluntarily organized and membership-based sport's potential as a physical activity promoter in order to act as a counteracting force against differences in participation and health between groups in society. The evaluation of the SSC and NSO representatives' practical arguments of how ideas on public health are implemented within their respective organizations shows how stated health related goals are being compromised by other values underlying the described means taken. Thus, actions can be viewed as insufficient in view of the goal of public health, since the values and concerns, such as sport performance enhancement and competitive sport, informing the actions taken are differing in stance. These findings are in line with previous studies showing that the main convention in sport is competitiveness and that sport representatives' arguments for health "seem to be manifested in rhetoric, symbolic or legislative processes" rather than being regulative for social practice (Skille, 2011, p. 250) and sport's difficulties to change in order to act on ideas that are not in line with its organizational self-identity (Stenling, 2013). Similarly, actions taken to reach new target groups (in the name of equality) can be seen as insufficient when the values and concerns informing the actions are about growing memberships and gaining legitimacy and funding for traditional competitive sports. A consequence of gaining more members on such basis would possibly imply a continued imbalance in terms of sport participation and distribution of health between different social groups in society. A consequence of 
lobbying and advocating "for sport" in the name of public health can result in continued support for the sport movement for actions not prioritized in practice. Especially in the light of aforementioned research (Skille, 2011; Stenling, 2013) that supports the indications in this study, that health issues may not necessarily be the regulating concern for the actions taken in practice in the name of public health. A consequence of allocating grants to short-term efforts and specific "inclusion-targeted projects" can allow regular competitive sport activities to remain unchanged. This conclusion is supported by previous studies (Fahlén \& Karp, 2010; Fahlén, Eliasson, \& Wickman, 2014) that have shown that even targeted efforts to develop alternative sport activities in order to attract new target groups have not been successful. Scholars (Coalter, 2007) have argued for the need for a cultural and structural change from within sport organizations in order for change to occur. The respondents in this study all refer to an ongoing restructuring of their organizations in order to change and broaden their activities and thereby their target groups, but it is shown that the actions taken to work internally in influencing the organizations to review their operations and activities (in the name of democracy) have resulted in a more limited range of targeted public health activities, possibly limiting the organizations' abilities to contribute to a more equal distribution of health between different social groups.

The findings of this article indicate some implications for sport practice and public health as well as for future research. First, a vulnerability in the SSC's potential to promote participation and inclusion from a public health perspective is the duty to act on members' behalf. Even if the sport movement at a strategic level had an ambition to broaden the uptake of members based on the goal to reach public health defined vulnerable groups in society, it is the members at an operative level that determine the actions and activities, and ultimately the target population really being prioritized. Previous studies have shown sport's difficulties in attracting, including and prioritizing minorities and vulnerable groups, and problems in relying on civil society organizations for this (Girginov, 2008; Morgan, 2013; Stenling, 2014; Thorpe, 2014; Wickman, 2011). The challenge for the sports movement is to regard equality, inclusion and equal opportunities to physical activity and health from a population perspective when in fact the member perspective is an obligation. Secondly, if the inherent values and concerns of the SSC's members are supporting traditional competitive sport ideals, the main challenge is to design and carry out actions and activities that are effective in relation to public health related goals. Another finding with implications for "sport for public health" practice and research is the argument that is taken for granted that sport equals physical activity, a circumstance pre- viously problematized by scholars (Coalter, 2007). It has been argued that if sport is intended to improve citizens' health, then more thought should be given to what kinds of physical activities should be encouraged. The contradictions between the representatives' normative discourse on how sport is significant for and contributes to public health, and the practical arguments of the actions and means taken in practice, takes place in the space of freedom enabled by the way sport is governed by the state-referred to by researchers as the implicit contract (Norberg, 2011). These circumstances raise further questions about governments' use of voluntary and membership-based non-profit organizations to achieve public health goals. Also, it demonstrates a need for further studies on how public health promotion is put into practice on a strategic and operative sport level-in order to better understand the potential for sport to act as a counteracting force against differences in sport participation and health between groups in society.

\section{Acknowledgements}

The authors would like to give thanks to The Swedish National Centre for Research in Sports for their financial support of the research on which this article is based.

\section{Conflict of Interests}

The authors declare no conflict of interests.

\section{References}

Adams, A. (2011). Between modernization and mutual aid: The changing perceptions of voluntary sports clubs in England. International Journal of Sport Policy and Politics, 3(1), 23-43.

Agergaard, S., \& Michelsen la Cour, A. (2012). Governing integration through sport. A case study of civil society involvement in welfare policy. Nordic Journal of Migration Research, 2(1), 26-34.

Bairner, A. (2010). What's Scandinavian about Scandinavian sport? Sport in Society, 13(4), 734-743.

Bergsgard, N. A., \& Norberg, J. R. (2010). Sports policy and politics-The Scandinavian way. Sport in society, 13(4), 567-582.

Bloyce, D., \& Smith, A. (2010). Sport policy and development. An introduction. New York: Taylor \& Francis.

Bolling, H. (2005). Sin egen hälsas smed. Idéer, initiativ och organisationer inom svensk motionsidrott 19451981 [Your own health's blacksmith. Ideas, initiatives and organizations within Swedish recreational sport 1945-1981]. (Doctoral dissertation). Retrieved from DiVA.

Bryman, A. (2008). Samhällsvetenskapliga metoder [Methods in social science] (B. Nilsson övers). Malmö: Liber. 
Centrum för idrottsforskning (2013). Statens stöd till idrotten-uppföljning 2012 [Government support to sport-follow up 2012]. Stockholm: Centrum för idrottsforskning.

Coalter, F. (2007). A wider social role for sport. Who's keeping the score? New York: Routledge.

Collins, M. (2010). Examining sports development. New York: Taylor \& Francis group.

Fahlen, J., Eliasson, I., \& Wickman, K. (2014). Resisting self-regulation: An analysis of sport policy programme making and implementation in Sweden. International Journal of Sport Policy and Politics, Doi:10.1080/19406940.2014.925954

Fahlen, J., \& Karp, S. (2010). Access denied: The new "Sports for all"-programme in Sweden and the reinforcement of the "Sports performance"-logic. Sport \& EU Review: The Review of the Association for the Study of Sport \& the European Union, 2(1), 1-48.

Fairclough, I., \& Fairclough, N. (2012). Political discourse analysis. A method for advanced students. London: Routledge.

Fairclough, N. (1992). Discourse and social change. UK: Polity press.

Fiske, J. (1994). Media matters. Everyday culture and political change. Minneapolis: University of Minnesota Press.

Friis Thing, L., \& Ottessen, L. (2010). The autonomy of sports: Negotiating boundaries between sports governance and government policy in the Danish welfare state. International Journal of Sport Policy, 2(2), 223-235.

Garrett, R. (2004). The response of voluntary sports clubs to Sport England's Lottery funding: Cases of compliance, change and resistance. Managing Leisure, 9(1), 13-29.

Girginov, V. (2008). Management of sports development. Oxford: Elsevier.

Grix, J., \& Carmichael, F. (2012). Why do governments invest in elite sport? A polemic. International Journal of Sport Policy and Politics, 4(1), 73-90.

Harris, S., Mori, K., \& Collins, M. (2009). Great expectations: Voluntary sports clubs and their role in delivering national policy for English sport. Voluntas, 20, 405-423.

Hartmann, D., \& Kwauk, C. H. (2011). Sport and development: An overview, critique, and reconstruction. Journal of Sport and Social Issues, 35(3), 284-305.

Hylton, K., \& Bramham, P. (2001). Sports development. Policy, process and practice. New York: Taylor \& Francis group.

Ibsen, B. (2002). Evaluering af det idrætspolitiske idéprogram [Evaluation of the ideaprogramme sport policy]. Copenhagen, Denmark: Københavns Universitet and Institut for forskning i Idræt og Folkelig Oplysning.

Kelly, J. (2012). Popular culture, sport and the "hero"- fication of British militarism. Sociology, 47(4), 722738.

Kvale, S., \& Brinkmann, S. (2009). Den kvalitativa forskningsintervjun [The qualitative research interview] (2 uppl). Lund: Studentlitteratur.

May, T., Harris, S., \& Collins, M. (2012). Implementing community sport policy: Understanding the variety of voluntary club types and their attitudes to policy. International Journal of Sport Policy and Politics, 5(3), 397-419.

Morgan, H. (2013). Sport volunteering active citizenship and social capital enhancement: What role in the big society. International Journal of Sport Policy and Politics, 5, 381-395.

Mutz, M., \& Baur, J. (2009). The role of sports for violence prevention: Sport club participation and violent behaviour among adolescents. International journal of sport policy, 1(3), 305-321.

Nichols, G., Padmore, J., Taylor, P., \& Barrett, D. (2012). The relationship between types of sports club and English government policy to grow participation. International Journal of Sport Policy and Politics, 4(2), 187-200.

Norberg, J. R. (2011). A contract reconsidered? Changes in the Swedish state's relation to the sports movement. International Journal of Sport Policy and Politics, 3(3), 311-325.

Norberg, J. R. (2004). Idrottens väg till folkhemmetstudier i statlig idrottspolitik 1913-1970 [Sport's road to the welfare state: Studies in swedish government policy towards sport, 1913-1970]. Stockholm: SISU Idrottsböcker.

Norberg, J. R. (2002). Idrottsrörelsen och staten. In J. Lindroth and J. R. Norberg (Eds.), Riksidrottsförbundet 1903-2003 [The Swedish Sports Confederation 1903-2003]. Stockholm: Informationsförlaget, 181-231.

O'Gorman, J. (2011). Where is the implementation in sport policy and programme analysis? The English Football Association's Charter Standard as an illustration. International Journal of Sport Policy and Politics, 3(1), 85-108.

Patton, M. Q. (2002). Qualitative research \& evaluation methods ( $3^{\text {rd }}$ ed.). London: SAGE.

Rich, K. A., \& Giles, A. R. (2014). Examining whiteness and Eurocanadian discourses in the Canadian Red Cross' Swim Program. Journal of Sport and Social Issues, 38(5), 465-485.

Riksidrottsförbundet (2009). Idrotten vill [What sport wants]. Stockholm: Riksidrottsförbundet.

Riksidrottsförbundet (2007). Idrott hela livet. Strategisk plan för idrottsrörelsens folkhälsoarbete [Sports throughout life. Strategic plan for the sport movement's public health work]. Stockholm: Riksidrottsförbundet.

Simon-Maeda, A. (2013). The Americanization of Daisuke Matsuzaka: a textual analysis of sports me- 
dia discourse. Continuum: Journal of Media \& Cultural Studies, 27(6), 913-933.

Skille, E. Å. (2009). State sport policy and voluntary sport clubs: The case of the Norwegian sports city program as social policy. European Sport Management Quarterly, 9(1), 63-79.

Skille, E. Å. (2010). Competitiveness and health: The work of sport clubs as seen by sport clubs representatives-A Norwegian case study. International Review for the Sociology of Sport, 45(1), 73-85.

Skille, E. A. (2011). The conventions of sport clubs: enabling and constraining the implementation of social goods through sport. Sport, Education and Society, 16(2), 241-253.

Skille, E. Å., \& Solbakken, T. (2011). Sport as a vehicle for health promotion-An analysis of Norwegian policy documents. Critical Public Health, 21(2), 191202.

Skille, E. Å, \& Waddington, I. (2006). Alternative sport programmes and social inclusion in Norway. European Physical Education Review, 12(3), 251-271.

SOU. (2000). Hälsa på lika villkor. Nationella mål för folkhälsan [Health on equal terms. National targets for public health]. Stockholm, Sweden: Statens offentliga utredningar.

Stenling, C. (2014). The emergence of a new logic? The theorizing of a new practice in the highly institutionalized context of Swedish voluntary sport. Sport Management Review, 17(4), 507-519.

Stenling, C. (2013). Sport programme implementation as translation and organizational identity construc- tion: The implementation of Drive-in sport in Sweden as an illustration. International Journal of Sport Policy and Politics, 6(1), 55-69.

Stenling, C., \& Fahlén, J. (2009). The order of logics in Swedish sport-feeding the hungry beast of result orientation and commercialization. European Journal for Sport and Society, 6(2), 121-134.

Theeboom, M., Haudenhuyse, R., \& De Knop, P. (2010). Community sports development for socially deprived groups: a wider role for the commercial sports sector? A look at the Flemish situation. Sport in society, 13(9), 1392-1410.

Theeboom, M., Schaillée, H., \& Nols, Z. (2012). Social capital development among ethnic minorities in mixed and separate sport clubs. International Journal of Sport Policy and Politics, 4(1), 1-21.

Thorpe, H. (2014). Action sports for youth development: Critical insights for the SDP community. International Journal of Sport Policy and Politics. doi:10.1080/19406940.2014.925952

Vuori, I., Lankenau, B., \& Pratt, M. (2004). Physical activity policy and program development: The experience in Finland. Public health reports, 119, 331-345.

Wickman, K. (2011). The governance of sport, gender and (dis)ability. International Journal of Sport Policy and Politics, 3(3), 385-399.

Österlind, M., \& Wright, J. (2014). If sport's the solution then what's the problem? The social significance of sport in the moral governing of "good" and "healthy" citizens in Sweden, 1922-1998. Sport, Education and Society, 19(8), 973-990.

\section{About the Authors}

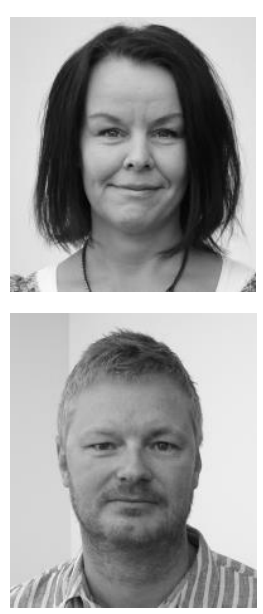

\section{Anna Aggestål}

Anna Aggestål is a PhD Student in Education at the Department of Education, Umeå University, Sweden. Her PhD project focuses on the Swedish Sports Confederation (a voluntary, non-profit and membership-based sport organization) and its role in national public health promotion.

\section{Dr. Josef Fahlén}

Dr. Josef Fahlén is Associate Professor in Education at the Department of Education, Umeå University, Sweden. His research is concerned with sport policy making and implementation in general and more specifically with the use of voluntary, non-profit and membership-based sport clubs as vehicles for social change. 